\title{
Design factors affecting the formation of the air-fuel mixture and the process of combustion in compression ignition engines
}

\author{
The paper provides information on the research and development works related to the design of diesel engines including \\ the improvement of fuel combustion processes and reduction of its consumption, and limitation of exhaust emissions. \\ Keywords: combustion engine, fuel, combustion, exhaust emissions
}

\section{Czynniki konstrukcyjne kształtujące proces tworzenia mieszanki paliwowo-powietrznej i spalania w silniku o zapłonie samoczynnym}

\author{
W referacie zamieszczono informacje z zakresu prac badawczo-rozwojowych zwiąanych z konstrukcja silników \\ o zapłonie samoczynnym, w tym doskonalenia procesów spalania paliwa i ograniczenia jego zużycia oraz zmniejszenia \\ emisji toksycznych sktadników spalin. \\ Słowa kluczowe: silnik spalinowy, paliwo, proces spalania, emisja spalin
}

\section{Introduction}

The prospects for the development of wheel transport indicate that a combustion engine will continue to be the most popular source of vehicle propulsion. Much more stringent concepts concerning exhaust and noise emissions as well as reduction of fuel consumption are new challenges for the designers of powertrains. Continuously conducted research and development works aim at improving the existing designs with respect to durability and efficiency as well as environmental performance (particularly in terms of a reduction of the emissions of $\mathrm{NO}_{x}, \mathrm{PM}$ and noise [1]). The improvement of these solutions requires a variety of investigations on the stages of design and improvement, introduction of technologically advanced fuels and during service life and repairs.

Important technical requirements are the processes of preparation of the mixture of atomized fuel inside the combustion chamber. A common feature of modern combustion engines is their growing complexity, hence demanding requirements for maintaining the cleanliness of the components of the fuel system and the combustion chamber.

\section{The influence of the quality of the fuel atomization in a diesel engine for the combustion process}

The quality of the fuel atomization influences the macrostructure and the microstructure of the atomized fuel dose and the preparation of the air fuel mixture inside the cylinder. Fuel must be introduced into the combustion chamber with a spray shaped in such a way that its droplets are in motion against the air moving inside the combustion chamber. The designers shape the intake ducts, the intake valves and the combustion chamber so that the air moving inside the cylinder creates swirl facilitating fuel evaporation. All the

\section{Wstęp}

Perspektywy rozwoju transportu kołowego wskazują, że tłokowy silnik spalinowy będzie $w$ dalszym ciągu powszechnie stosowanym źródłem napędu pojazdów samochodowych. Zdecydowanie ostrzejsze unormowania dotyczące emisji spalin i hałasu, jak również ograniczenia zużycia paliwa stanowią nowe wyzwania dla konstruktorów jednostek napędowych. Prowadzone ustawicznie prace badawcze mają na celu doskonalenie konstrukcji w aspekcie wzrostu niezawodności i sprawności, ale także proekologiczności, ukierunkowane są szczególnie na ograniczenie emisji szkodliwych zanieczyszczeń $\mathrm{NO}_{x}$ i PM oraz hałasu [1]. Doskonalenie tych rozwiązań wymaga różnorodnych badań, zarówno na etapie powstawania i ulepszania konstrukcji, wprowadzania zaawansowanych technologicznie paliw zastępczych, jak również w okresie eksploatacji i napraw.

Istotnym wymaganiem technicznym stanowią procesy przygotowania mieszanki rozpylonej strugi paliwa w komorze spalania silnika. Wspólną cechą współczesnych silników spalinowych jest ich rosnąca złożoność, a co za tym idzie wzrastające wymagania dotyczące utrzymania czystości elementów układu paliwowego i komór spalania silnika.

\section{Wpływ jakości rozpylenia paliwa w silniku o zapłonie samoczynnym na przebieg procesu spalania}

Jakość rozpylenia paliwa wpływa na makrostrukturę i mikrostrukturę rozpylonej strugi paliwa i przygotowanie mieszanki paliwowo-powietrznej w cylindrze. Paliwo musi być wprowadzane strugą tak ukształtowaną aby zapewnić względny ruch jego kropel w stosunku do powietrza przemieszczającego się wewnątrz komory spalania. Konstruktorzy tak kształtują kanały i zawory dolotowe a także komorę spalania, aby przemieszczające się w cylindrze 
above actions must be well synchronized with the injected fuel spray. Initially, in diesel engines of passenger vehicles the injection was realized to a pre-chamber in the cylinder head, as shown in Fig. 1a, referred to as a swirl chamber due to the air stream formation inside it. This facilitated the engine start and a reduced engine noise. The temperature of the walls of the pre-chamber stabilizes faster and remains on a higher level than the temperature of the wall inside the combustion chamber used in direct injected engines, as shown in Fig. 1b; this facilitates self-ignition and reduces
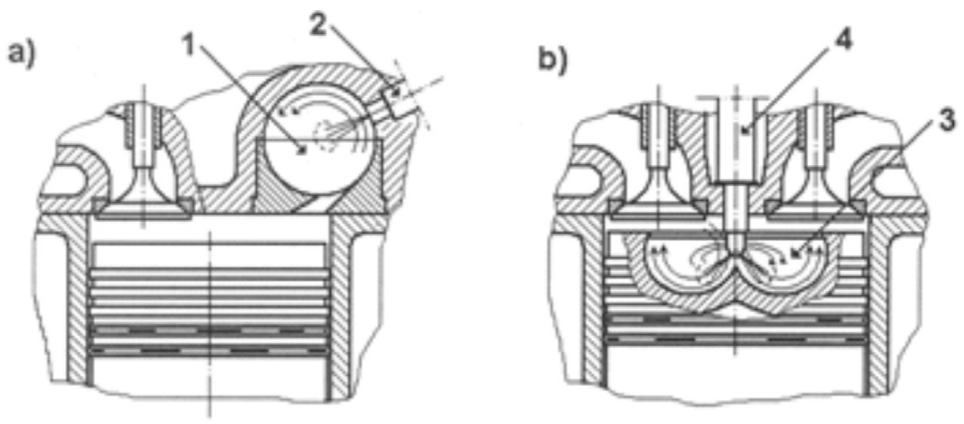

Fig. 1. Combustion chamber of diesel engines: a) swirl chamber (indirect injection), b) formed in the piston crown (direct injection); 1 - swirl chamber, 2 - pintle nozzle,

3 - recess in the piston crown 4 - multi-hole nozzle (*arrows indicate the direction of the air movement inside the chamber)

Rys. 1. Komory spalania silników o zapłonie samoczynnym: a) wirowa (wtrysk pośredni), b) ukształtowana $w$ denku tłoka (wtrysk bezpośredni): 1-komora wirowa,

2 - rozpylacz czopikowy, 3 - komora $w$ denku ttoka 4 - rozpylacz wielootworowy ( ${ }^{*}$ strzałki wskazuja uksztaltowanie strug powietrza wewnątrz komór)

its delay [2].

In order to properly form the spray of the fuel injected into the combustion chamber we need to use many types of fuel injectors. A pintle injector introduces the fuel through a conical spray into the stream of the swirled air inside the combustion chamber of a direct injected engine. The nozzle needle has a protruding conical pintle at the end. The needle is pressed against the seat by the force of the spring. Under the pressure exerted on the lower conical part of the needle the fuel lifts it and overcoming the force of the spring and flowing around the needle is diverted to form a cone. The shape of the pintle defines the angle of the fuel spray cone (most often $10^{\circ}$ to $30^{\circ}$ ). The vertical angle should be relatively wide because to the benefits of the extension of the fuel-air contact area. In pintle injectors the quality of the workmanship of the needle journal is very important. Even little imperfections may change the shape and structure of the fuel spray as well as the size of the droplets and the spray front propagation velocity. Figure 2 presents the nozzle with a cylindrical pintle (a) and a conical pintle (b).

Nozzles with a cylindrical pintle generate a compact spray of fuel droplets of high penetration. The needle has a cylindrical pintle with a conical face. Nozzles with a conical pintle generate a spray of fuel droplets of greater atomization angle and reduced penetration as compared to those having a cylindrical pintle. This results from a characteristic shape of the pintle that has a cylindrical damper and a conical nozzle. silnika powietrze tworzyło zawirowania sprzyjające odparowaniu paliwa. Muszą one być ściśle zsynchronizowane ze strugą wtryskiwanego paliwa. Początkowo w silnikach samochodów osobowych o zapłonie samoczynnym najczęściej stosowano wtrysk do wstępnej komory znajdującej się w głowicy silnika pokazanej na rys. 1a, nazywanej z uwagi na ukształtowanie strugi powietrza w jej wnętrzu, komorą wirową. Wiązało się to z łatwiejszym rozruchem i mniejszą hałaśliwością pracy silnika. Temperatura ścianek komory wstępnej szybciej stabilizuje się i utrzymuje się na wyższym poziomie niż temperatura ścianek komory w tłoku, stosowanej przy wtrysku bezpośrednim, przedstawionej na rys. $1 \mathrm{~b}$; ułatwia to samozapłon i skraca jego opóźnienie [2].

W celu odpowiedniego ukształtowania strugi wtryskiwanego paliwa do komory spalania, konieczne jest zastosowanie różnych rozwiązań konstrukcyjnych wtryskiwaczy (typów). Wtryskiwacz czopikowy wprowadza paliwo stożkową strugą w strumień zawirowanego powietrza w komorze wstępnej silnika z wtryskiem pośrednim. Iglica rozpylacza zakończona jest czopikiem walcowym lub stożkowym, który wystaje poza rozpylacz. Iglica jest dociskana do gniazda siłą sprężyny. Pod wpływem ciśnienia paliwa na dolną stożkową powierzchnię iglicy wtryskiwane paliwo unosi iglicę pokonując nacisk sprężyny i opływając czop iglicy wtryskiwacza, ulega odchyleniu w stożek. Kształt czopika determinuje wielkość kąta wierzchołkowego stożka rozpylanego paliwa (najczęściej od $10^{\circ}$ do $30^{\circ}$ ). Powinien on być możliwie duży, ze względu na korzyści płynące z powiększenia powierzchni styku paliwo-powietrze. We wtryskiwaczach czopikowych bardzo istotna jest dokładność wykonania czopa. Nawet małe niedokładności potrafią zmienić kształt i strukturę rozpylonej strugi paliwa oraz zmianę średnic kropel i prędkość rozchodzenia się czoła strugi. Na rysunku 2 przedstawiono rozpylacze z czopikiem cylindrycznym (a) i czopikiem stożkowym (b).

Rozpylacze z czopikiem cylindrycznym wytwarzają zwartą strugę kropel o dużym zasięgu i małym kącie rozpylenia. Iglica jest zakończona cylindrycznym czopikiem ze stożkową przylgnią. Rozpylacze z czopikiem stożkowym wytwarzają strugę kropel o zwiększonym kącie rozpylenia a)

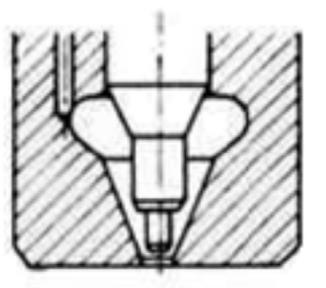

b)

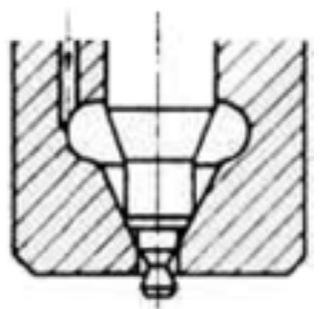

Fig. 2. Pintle nozzles a) with a cylindrical pintle, b) with a conical pintle Rys. 2. Rozpylacze czopikowe a) z czopikiem cylindrycznym, b) z czopikiem stozkkowym 
When selecting the length of the pintle against its lift we may obtain such flow cross-sections that will ensure the most convenient division of the fuel dose into individual injection stages. A multi-hole injector distributes the fuel in the form of several fuel sprays adapted to the shape of the combustion chamber and the swirls inside it. Due to the fact that the thermodynamic efficiency of engines having a pre-chamber is lower than that of direct injected engines direct injection became a priority for designers of small size diesel engines. Lower thermal efficiency of indirect injected engines results from the presence of an additional volume of the combustion chamber connected with the cylinder through a relatively narrow channel, which results in energy losses related to the flow of the charge and the difference in pressures between the swirl chamber and the space above the piston that not only reduces the pressure increment rate in the cylinder but also its maximum value. The introduction of a direct central injection to the combustion chamber in the piston allows an application of multi-hole injectors (common rail or unit injectors) that more efficiently distribute the injected fuel inside the combustion chamber.

In the Common Rail system the fuel is sucked from the fuel tank under a pressure of approximately $0.4 \mathrm{MPa}$ and is directed to the high-pressure pump through a filter. The high-pressure pump compresses the fuel to the pressure from $180 \mathrm{MPa}$ to $220 \mathrm{MPa}$ and pumps it further to the accumulator connected with the injectors. At the moment of injector opening the pressure of the fuel injected to the combustion chamber is almost equal to the pressure of the accumulator. The accumulator pressure is adjusted by a pressure valve. The high-pressure pump and the injectors are controlled with an electronic controller that continuously meters the fuel and controls the operation of the pump and the injectors. The

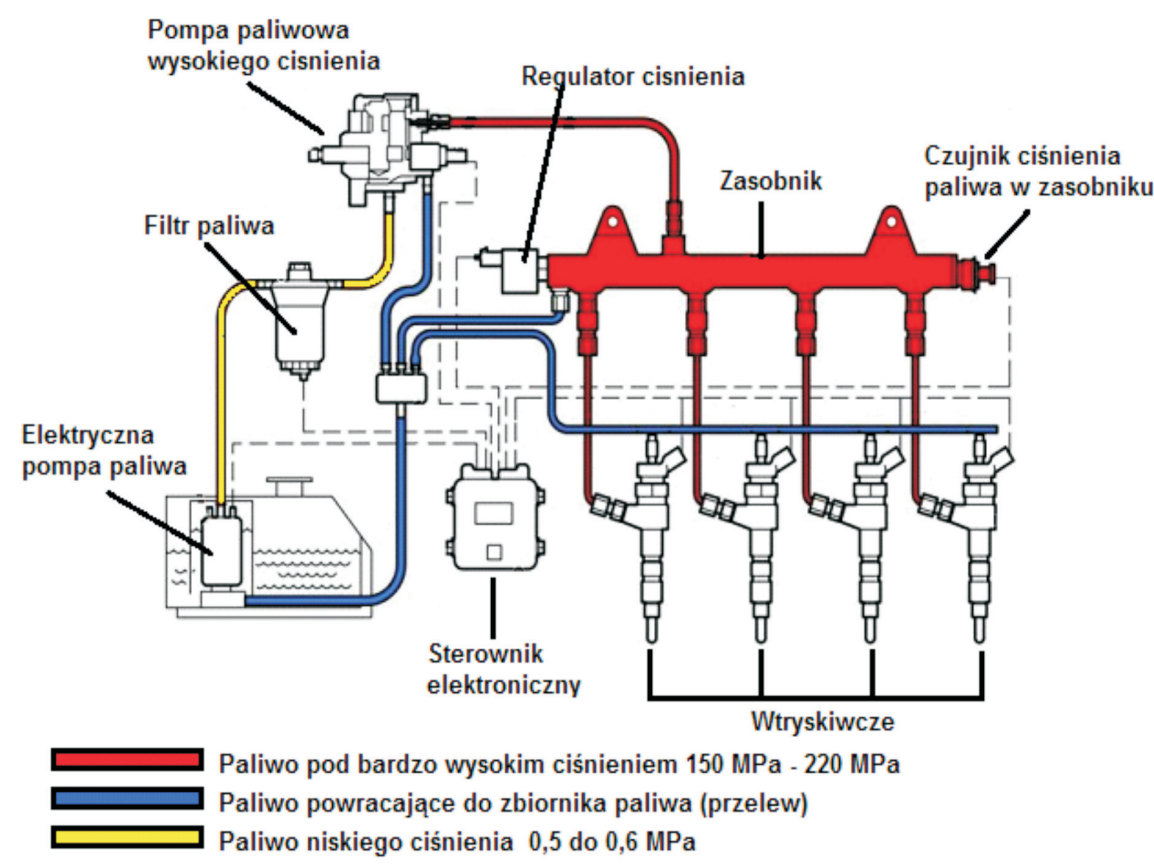

Fig. 3. The common rail injection system Rys. 3. Uktad wtryskowy common rail i skróconym zasięgu strugi w porównaniu z rozpylaczami z czopikiem cylindrycznym. Wynika to z charakterystycznego kształtu czopika, który składa się z cylindrycznego dławika i stożkowego rozpylacza. Dobierając długość czopika do jego skoku, można uzyskać takie przekroje przepływowe, które zapewniają najdogodniejsze rozdzielenie dawki paliwa na poszczególne fazy wtrysku. Natomiast wtryskiwacz wielootworowy rozprowadza paliwo w postaci kilku strug dostosowanych do ukształtowania komory w tłoku i zawirowań powietrza w jej wnętrzu. Z uwagi na to, że sprawność termodynamiczna silników z komorą wstępną jest niższa od sprawności silników z wtryskiem bezpośrednim, zastosowanie wtrysku bezpośredniego stało się jednym $\mathrm{z}$ priorytetowych zadań dla konstruktorów małogabarytowych silników o zapłonie samoczynnym. Niższa sprawność termodynamiczna silników z wtryskiem pośrednim wynika z obecności dodatkowej objętości komory spalania połączonej stosunkowo wąskim kanałem z wnętrzem cylindra, co powoduje straty energetyczne związane z przepływem ładunku oraz różnicę ciśnień pomiędzy komorą wirową a przestrzenią nad tłokiem, która nie tylko zmniejsza szybkość przyrostu ciśnienia w cylindrze ale i obniża jego maksymalną wartość. Wprowadzenie bezpośredniego, centralnego wtrysku do komory spalania ukształtowanej w denku tłoka, pozwala na zastosowanie wtryskiwaczy wielootworowych (typu common rail lub pompowtryskiwaczy) lepiej rozprowadzających wtryskiwane paliwo we wnętrzu komory spalania.

W układzie common rail olej napędowy zasysany jest ze zbiornika paliwa pod ciśnieniem około $0,4 \mathrm{MPa}$ i poprzez filtr paliwa trafia do pompy wysokiego ciśnienia. Pompa wysokiego ciśnienia spręża paliwo do ciśnienia od $180 \mathrm{MPa}$ do $220 \mathrm{MPa}$ i tłoczy je do zasobnika, który jest połączony z wtryskiwaczami. W chwili otwarcia wtryskiwacza do komory spalania wtryskiwane jest paliwo o ciśnieniu prawie równym ciśnieniu w zasobniku. Za regulację ciśnienia w zasobniku odpowiedzialny jest zawór regulacji ciśnienia. Pompa wysokociśnieniowa oraz wtryskiwacze są sterowane przy użyciu elektronicznego sterownika, który na bieżąco odmierza wielkość dawki wtryskiwanego paliwa oraz steruje pracą pompy i wtryskiwaczy. Zastosowanie zasobnika ciśnienia oraz elektronicznego systemu sterowania pozwoliło systemowi common rail na możliwość dowolnego kształtowania dawki wtrysku. Dzięki podzieleniu dawki na kilka mniejszych, wzrosła sprawność pracy silnika o ZS oraz zmniejszeniu uległ hałas. Standardowy układ wtryskowy common rail przedstawiono na rysunku 3 [3].

W konwencjonalnych układach wtrysku paliwa z pompami 
application of an accumulator and an electronic controller enables the Common Rail system to freely adjust the dose of the injected fuel. By dividing the fuel dose into several smaller ones the efficiency of a diesel engine increases and the noise level drops. A standard common rail injection system has been shown in Fig. 3 [3].

In conventional fuel injection systems with distributor and inline injection pumps the fuel injection is limited. The combustion chamber is fed with the entire fuel dose as the main injection without a pilot injection and a post injection, which influences the course of the process of kinetic and diffusive air-fuel mixture combustion. In common rail systems the fuel injection may be realized independently of the crankshaft position and that enables:

- setting of any given pressure and time of the injection at different engine speeds and loads,

- creating of time characteristics of the injection and selection of the injection onset,

- an injection of a small pilot fuel dose,

- a post injection of fuel,

- selecting the dwell times between the end of the pilot injection and the onset of the main injection and the end of the main injection and the onset of the post injection,

- reproducibility of the injection parameters [4].

\section{The processes of air-fuel mixture formation, ignition and combustion in a diesel engine}

The processes of fuel injection, mixture formation and ignition and combustion are complex repetitive fast-varying processes depending on many physical and chemical parameters that take place in a combustion chamber of a diesel engine. The spray of atomized fuel mixes with compressed air forming a combustible air-fuel mixture. The parameters of the atomized fuel spray can be divided into external macro parameters (macrostructure of the fuel spray) and internal micro parameters (microstructure of the fuel spray) $[5,6]$.

Figure 4 presents the macrostructure of the atomized fuel spray [7].

The spray quality and the macrostructure of the atomized fuel spray are defined by the following three physical parameters $[7,8]$ : wtryskowymi rozdzielaczowymi i rzędowymi ograniczone są możliwości sterowania wtryskiem paliwa. Do komory spalania doprowadzona jest bowiem cała dawka paliwa jako wtrysk główny, bez wtrysku wstępnego (pilotującego) i dotrysku paliwa co wpływa na przebieg procesu kinetycznego i dyfuzyjnego spalania mieszanki paliwowopowietrznej. W układach common rail wtrysk paliwa może następować niezależnie od położenia wału korbowego a to umożliwia:

- zaprogramowanie dowolnego ciśnienia i czasu wtrysku przy różnych prędkościach obrotowych i obciążeniach silnika;

- kształtowanie czasowej charakterystyki wtrysku oraz doboru początku wtrysku;

- dokonanie wtrysku małej, pilotującej dawki paliwa;

- dotrysk małej dawki paliwa;

- dobór odstępów czasowych między końcem wtrysku pilotującego, a początkiem wtrysku głównego oraz końcem wtrysku głównego i początkiem dotrysku;

- zapewnienie powtarzalności wszystkich parametrów przebiegu wtrysku [4].

\section{Procesy tworzenia mieszanki paliwowo-powietrznej, jej zapłonu i spalania w silniku o ZS}

Procesy wtrysku paliwa, tworzenia mieszaniny paliwa i powietrza jej zapłonu oraz spalania są złożonymi, powtarzającymi się okresowo szybkozmiennymi procesami zależnymi od wielu parametrów fizykochemicznych paliwa zachodzącymi w komorze spalania silnika o zapłonie samoczynnym. Struga rozpylonego paliwa odparowuje i miesza się $\mathrm{z}$ powietrzem sprężonym w komorze spalania tworząc mieszaninę paliwowo-powietrzną. Parametry rozpylonej strugi paliwa można podzielić na makroparametry zewnętrzne (makrostrukturę strugi) i mikroparametry wewnętrzne(mikrostrukturę strugi) [5,6].

Na rysunku 4 przedstawiono makrostrukturę rozpylonej strugi paliwa [7].

Jakość rozpylenia i makrostrukturę rozpylonej strugi paliwa określają następujące trzy parametry fizyczne [7, 8]:

- zasięg czoła strugi rozpylonego paliwa (penetracja strugi);

- kąt wierzchołkowy strugi $(\Theta)$;

- zasięg rozpadu strugi paliwa pierwotny i wtórny.

Podstawowym parametrem charakteryzującym mikrostrukturę rozpylonego strumienia paliwa jest widmo rozpylenia czyli rozkład kropel według średnic i prędkości w strudze. $[4,9,10]$.

Dla potrzeb analizy tworzenia strugi paliwa najczęściej stosuje się pomiar średniej objętościowo-powierzchniowej średnicy kropel Sautera (oznaczane jako $\mathrm{d}_{32} \operatorname{lub}_{\mathrm{SMD}}$ ) czyli średnicy zastępczej, którą miałyby hipotetyczne krople jednakowego wymiaru gdyby ich całkowita powierzchnia 
- fuel spray front penetration;

- vertical angle of the fuel spray $(\Theta)$;

- the primary and the secondary range of the fuel spray decomposition.

A fundamental parameter characterizing the microstructure of the atomized fuel spray is the spectrum of the atomization i.e. the diameter and velocity based distribution of the droplets in the spray. $[4,9,10]$.

For the purpose of the analysis of the fuel spray formation the most frequently applied measurement is that of volumetrically averaged Sauter surface diameter (marked $\mathrm{d}_{32}$ or $\mathrm{d}_{\text {SMD }}$ )- a replacement diameter that hypothetical droplets of the same size would have if their total area and total volume were the same as in an actual droplet of a non-spherical shape [10, 11].

An average diameter of a droplet of an atomized fuel spray is a function of four Weber's Laplace's or Ohnesorge's similarity numbers and the ratio of the density and dynamic viscosity of the gaseous medium (air charge) [11, 12, 13].

The parameters defining the macrostructure of the fuel spray (fuel spray penetration, fuel spray vertical angle, primary and secondary range of fuel spray decomposition) and the microstructure of the atomized fuel spray (distribution of the fuel droplet velocity in the fuel spray and the distribution of average droplet diameters) are tightly related to one another and significantly influence the preparation of an appropriate composition of the mixture defined by the excess air coefficient $\lambda$ or the coefficient of stoichiometry $\phi[14,15]$.

An optimum course of the combustion process in a diesel engine according to Hiroyasu i Arai [16] depends on many factors, the most significant of which are:

- the design of the engine intake system, combustion chamber, i całkowita objętość były takie same jak rzeczywistej kropli o kształcie niekulistym. [10, 11].

Średnia średnica kropli rozpylonego paliwa jest funkcja czterech liczb podobieństwa Webera, Laplace'a lub Ohnesorge'a oraz stosunku gęstości i lepkości dynamicznej paliwa do gęstości i lepkości dynamicznej ośrodka gazowego (ładunku powietrza) $[11,12,13]$.

Parametry określające makrostrukturę strugi paliwa (penetracja strugi, kąt wierzchołkowy strugi, zasięg rozpadu pierwotny i wtórny strugi) i mikrostrukturę rozpylonej strugi paliwa (rozkład prędkości kropel w strudze i rozkład średnich średnic kropel paliwa) są ze sobą ściśle powiązane i w sposób istotny wpływają na przygotowanie należytego składu mieszanki paliwowo-powietrznej określonej współczynnikiem nadmiaru powietrza $\lambda$ lub współczynnikiem stechiometrii $\phi[14,15]$.

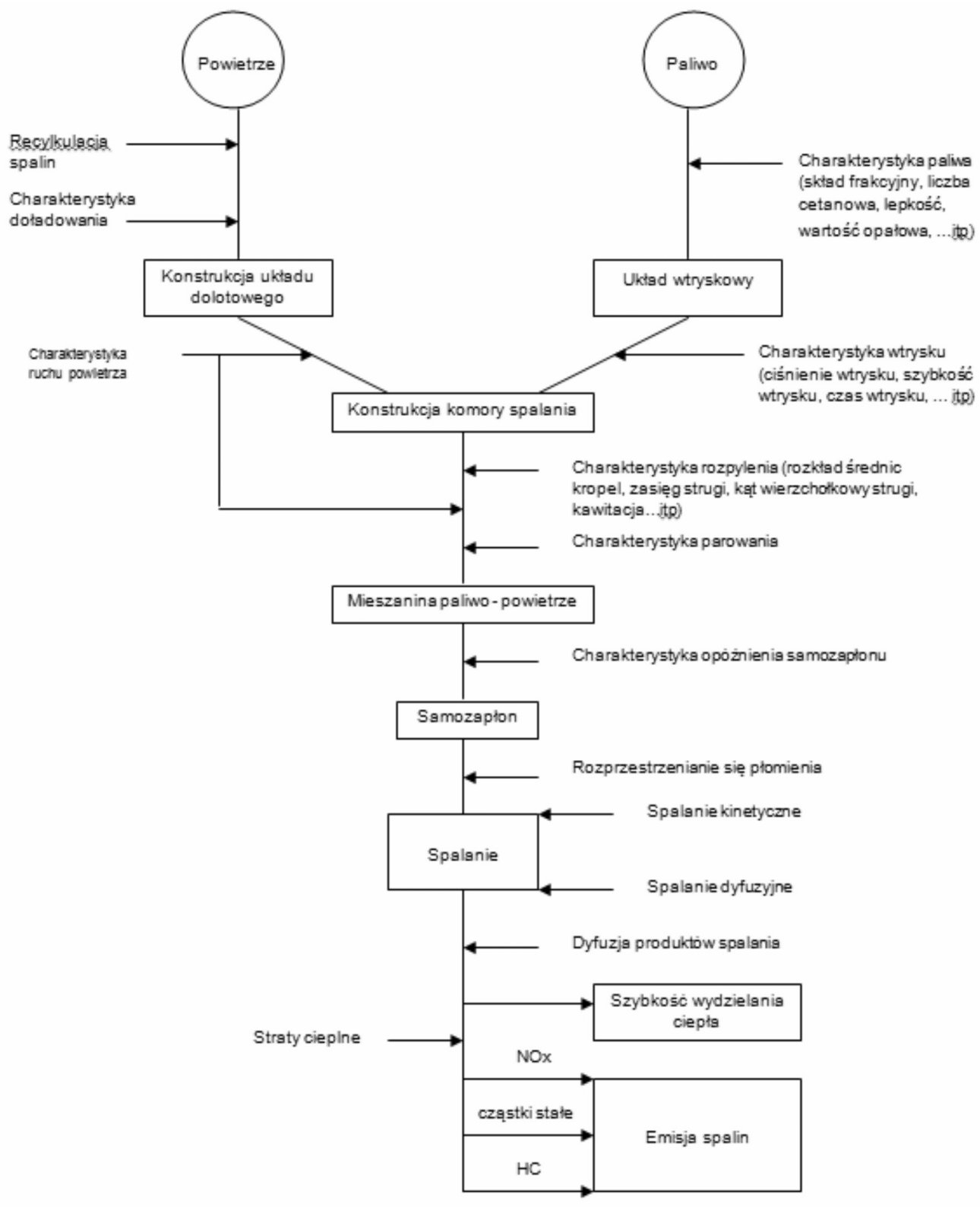

Fig. 5. Schematics of the process of diesel fuel combustion based on [16] Rys. 5. Schemat procesu spalania oleju napędowego na podstawie [16] 
injection system, types of injectors, exhaust gas recirculation and supercharging characteristics;

- the characteristics of the injection and atomization including the injection pressure, injection duration, injection velocity, fuel spray penetration, fuel spray vertical angle, distribution of the average Sauter diameter of the droplets, cavitation;

- the physical and chemical properties of fuel i.e. density, viscosity, fractional composition, cetane number, lubricity and many other important parameters influencing the injection process, the air-fuel mixture formation and the combustion.

Figure 5 presents schematics of the process of diesel fuel combustion including the process of injection, air-fuel mixture formation, self-ignition and combustion in a diesel engine [16].

\section{The influence of the phases of the process of injected diesel fuel spray as a function of the crankshaft angle on the exhaust emissions of $\mathrm{NO}_{x}$ and $\mathrm{PM}$}

Figure 6 presents the process of the injected diesel fuel spray in a direct injected diesel engine with the phases of the combustion process (as a function of the crankshaft angle) responsible for the for controlling the emissions of $\mathrm{NO}_{x}$ and PM $[17,18]$.

The time from the moment of the fuel injection until the onset of combustion (self-ignition delay) depends on the physical and chemical properties of the diesel fuel such as viscosity, evaporation rate, and fractional composition. The process of kinetic combustion of the diesel fuel injected to the combustion chamber during the time of self-ignition delay is related to the lack of time for mixing of the fuel with air. The consequence is a formation of local zones of high excess air coefficient, which reduces the emission of PM, carbon monoxide and unburned hydrocarbons. The ignition of the airfuel mixture results in a dynamic combustion with a high velocity, an increase in the pressure and temperature in the combustion chamber but it leads to a formation of nitric oxides and generates noise. After the period o kinetic combustion diffusive combustion takes place. The process of heat release rate during diffusive combustion depends mainly on the intensity of the formation of the air-fuel mixture that is influenced by cavitation, diffusive processes, turbulence and the physico-chemical properties of the fuel [19].

Figure 7 presents a conceptual model of the mechanism of a fuel spray combustion in a diesel engine developed by Dec using optical and laser
Optymalny przebieg procesu spalania w silniku o zapłonie samoczynnym według Hiroyasu i Arai [16] zależy od wielu istotnych czynników z których najważniejsze to:

- konstrukcja układu dolotowego i komory spalania silnika, układu wtryskowego i rodzaj wtryskiwacza, recyrkulacja spalin i charakterystyka doładowania;

- charakterystyka wtrysku i rozpylenia w tym ciśnienie wtrysku, czas wtrysku, szybkość wtrysku, zasięg strugi paliwa, kąt wierzchołkowy strugi, rozkład średniej średnicy kropel Sautera, kawitacja;

- właściwości fizykochemicznych paliwa czyli lepkość, gęstość, skład frakcyjny, liczba cetanowa, smarność i wiele innych istotnych parametrów mających wpływ na proces wtrysku, tworzenia mieszanki paliwowo - powietrznej oraz proces spalania.

Na rysunku 5 przedstawiono schematycznie proces spalania oleju napędowego obejmujący proces wtrysku paliwa, tworzenia mieszaniny paliwo-powietrze, samozapłonu i spalania w silniku o zapłonie samoczynnym [16].

\section{Wpływ faz procesu wtryśniętej strugi ON w funkcji kąta obrotu wału korbowego silnika w ksztaltowaniu emisji $\mathrm{NO}_{x}$ i PM}

Na rysunku 6 przedstawiono przebieg procesu wtryśniętej strugi oleju napędowego w silniku o zapłonie samoczynnym $\mathrm{z}$ bezpośrednim wtryskiem $\mathrm{z}$ zaznaczeniem faz procesu spalania w funkcji kąta obrotu wału korbowego odpowiedzialnych za kontrolę emisji $\mathrm{NO}_{\mathrm{x}}$ i PM $[17,18]$.

Czas od chwili wtrysku paliwa do rozpoczęcia spalania (opóźnienie samozapłonu) zależy od właściwości fizykochemicznych oleju napędowego, lepkości, zdolności do 
techniques. It illustrates the development of the combustion process of a fuel spray in the form of a sequence of phenomena starting from the injection of fuel until its completion,

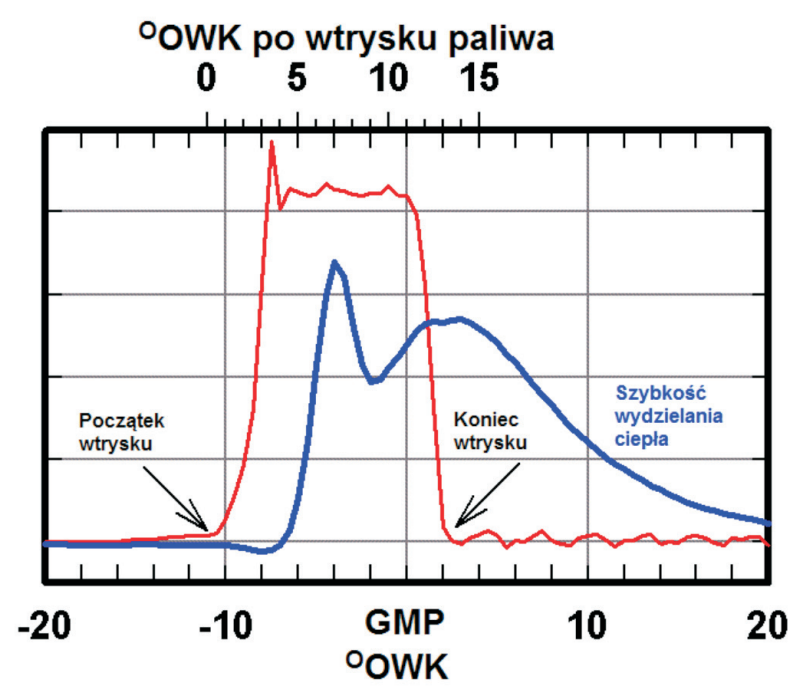

\section{$1.0^{\circ} \mathrm{OWK}$ $\circ$ \\ $2.0^{\circ} \mathrm{OWK}^{\circ}$}

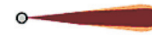

$3.0^{\circ} \mathrm{OWK}$

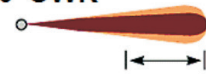

$4.0^{\circ} \mathrm{OWK}$

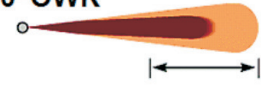

$4.5^{\circ} \mathrm{OWK}$

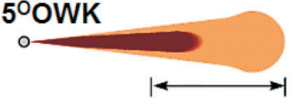

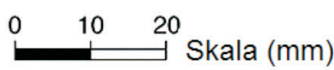

niskie wysokie

Stężenie sadzy $5.0^{\circ} \mathrm{OWK}$



$6.0^{\circ} \mathrm{OWK}$



$6.5^{\circ} \mathrm{OWK}$
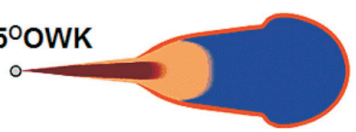

$8.0^{\circ} \mathrm{OWK}$
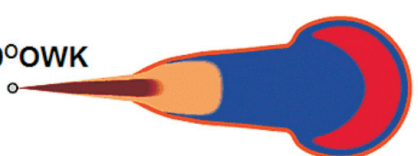

$10.0^{\circ} \mathrm{OWK}$

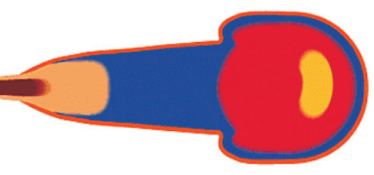

Paliwo ciekłe

Mieszanina par paliwa z powietrzem $(\phi=2-4)$

$\square$ Wielopierścieniowe węglowodory aromatyczne

_ Spalanie dyfuzyjne

$\leftrightarrow$ Chemiluminesencja

Fig. 7. Schematic diagram of fuel injection process based on the measurements using a laser technique [20]

Rys. 7. Schematyczny przebieg wtrysku paliwa na podstawie pomiarów z użyciem techniki laserowej [20] odparowania, składu frakcyjnego paliwa. Proces spalania kinetycznego oleju napędowego wtryśniętego do komory spalania w czasie okresu opóźnienia samozapłonu związany jest $\mathrm{z}$ brakiem czasu na wymieszanie paliwa $\mathrm{z}$ powietrzem. Konsekwencją tego jest powstawanie lokalnych stref z dużymi wartościami współczynnika nadmiaru powietrza co sprzyja niskiej emisji cząstek stałych, tlenku węgla i niespalonych węglowodorów. Jednocześnie zapłon mieszaniny paliwo-powietrze powoduje dynamiczny proces spalania $\mathrm{z}$ dużą prędkością, wzrost ciśnienia i temperatury w komorze spalania lecz generuje tworzenie tlenków azotu i emisję hałasu. Po okresie kinetycznego spalania następuje okres spalania dyfuzyjnego. Przebieg szybkości wywiązywania ciepła w okresie spalania dyfuzyjnego zależy głównie od intensywności procesu tworzenia mieszaniny paliwowo-powietrznej, na który wpływ mają kawitacja, procesy dyfuzyjne, turbulencja oraz właściwości fizykochemiczne paliwa [19].

Przedstawiony na rysunku 7 koncepcyjny model mechanizmu spalania strugi paliwa w silniku o zapłonie samoczynnym opracowany przez Deca z użyciem techniki optycznej i laserowej. Ilustruje on rozwój procesu spalania strugi paliwa w postaci sekwencji przebiegu zjawisk, począwszy od wtrysku paliwa aż do jego zakończenia w czasie mierzonym kątem obrotu wału korbowego. Początek wtrysku przyjęto za $0{ }^{\circ} \mathrm{OWK}$, co odpowiada $11,0^{\circ} \mathrm{OWK}$ przed górnym martwym położeniem tłoka (GMP). Przy kącie 1,0 ${ }^{\circ} \mathrm{OWK}$ po wtrysku paliwa występuje tylko ciekła struga paliwa. Przy kącie 2,0 ${ }^{\circ} \mathrm{OWK}$ do 3,0 ${ }^{\circ} \mathrm{OWK}$ po wtrysku paliwa ciekła struga paliwa osiąga maksymalny zasięg i zaczyna odparowywać. Przy kącie 4,0 ${ }^{\circ} \mathrm{OWK}$ po wtrysku paliwa przed ciekłą strugą tworzy się mieszanka paliwowo-powietrzna, a przy $4,5^{\circ} \mathrm{OWK}$ bogata mieszanina paliwa z powietrzem, która przy $(\phi=2-4)$ tworzy wir czołowy. Przy kącie 5,0 ${ }^{\circ} \mathrm{OWK}$ po wtrysku paliwa, temperatura $\mathrm{W}$ wirze czołowym strugi i bogatej mieszanki paliwopowietrze osiąga wartość $750 \mathrm{~K}$ i rozpoczyna się proces spalania kinetycznego z powstawaniem wielopierścieniowych węglowodorów aromatycznych (WWA) w czołowym strumieniu mieszanki. Przy kącie $6,0^{\circ} \mathrm{OWK}$ po wtrysku paliwa temperatura bogatej mieszanki paliwo-powietrze wzrasta z 825 K do 1600-1700 K generując oprócz WWA cząstki stałe sadzy, tlenek węgla i niespalone węglowodory. Przy kącie 6,5 ${ }^{\circ} \mathrm{OWK}$ po wtrysku paliwa tworzy się turbulentny płomień dyfuzyjny na obrzeżach płonącej strugi pomiędzy częściowo utlenionymi produktami bogatej mieszanki paliwowo-powietrznej a powietrzem otaczającym, którego temperatura wynosi około $2700 \mathrm{~K}$. Jednocześnie rozpoczyna się faza spalania dyfuzyjnego kontrolowanego mieszaniem oraz proces utleniania sadzy. Przy kącie 8,0 ${ }^{\circ} \mathrm{OWK}$ wewnątrz czołowego wiru zwiększa się koncentracja cząstek stałych sadzy, jednocześnie płomień dyfuzyjny nadal 
in the time measured by the crankshaft angle. The onset of the injection was assumed at zero crankshaft angle degrees (CAD), which corresponds to $11.0{ }^{\circ} \mathrm{CA}$ before the top dead centre. At $1.0^{\circ} \mathrm{CA}$ after the injection of fuel only liquid fuel spray occurs. At $2.0^{\circ} \mathrm{CA}$ to $3.0^{\circ} \mathrm{CA}$ after the fuel injection the fuel spray reaches its maximum penetration and begins to evaporate. At the angle of $4.0^{\circ} \mathrm{C}$.A., after the injection, before the liquid fuel spray an air-fuel mixture forms and at $4.5^{\circ} \mathrm{C}$.A. a rich air-fuel mixture is generated forming a front tumble at $(\phi=2-4)$. At the angle of $5.0^{\circ} \mathrm{C}$.A. after the injection the temperature in the front tumble of the fuel spray and its rich mixture part reaches the value of $750 \mathrm{~K}$ and the process of kinetic combustion begins when polycyclic aromatic hydrocarbons are formed (PAH) in the front of the mixture. At $6.0^{\circ} \mathrm{CA}$ after the injection the temperature of the rich air-fuel mixture increases from $825 \mathrm{~K}$ to $1600-1700 \mathrm{~K}$ generating (beside $\mathrm{PAH}$ ) particulate matter, carbon monoxide and unburned hydrocarbons. At $6.5^{\circ} \mathrm{CA}$ after the injection a turbulent diffusive flame forms on the verge of the burning fuel spray among the partly oxidized products of the rich air-fuel mixture and the ambient air whose temperature is approximately $2700 \mathrm{~K}$. At the same time the diffusive combustion phase controlled by the mixing and the process of soot oxidation is initiated. At $8.0^{\circ} \mathrm{CA}$ inside the front tumble the concentration of particulate matter increases and the diffusive flame is still a thin double layer between the burning fuel spray and the high temperature ambient air. At $10.0^{\circ} \mathrm{CA}$ after the injection the burning fuel spray reaches a quasi-steady state in which the front tumble formed in the front of the fuel spray increases the concentration of soot and results in its agglomeration to particles of 30 to $50 \mathrm{~nm}$.

Figure 8 presents an integrated model of the process of combustion of the fuel spray starting from the fuel injection until its end with the chemical processes and temperature distribution marked [20, 21].

A detailed description of the concept model confirmed by detailed tests utilizing various techniques has been presented in [22-28].

The fuel, of the temperature of $350 \mathrm{~K}$, injected into the combustion chamber mixes with hot air (950 K) and evaporates forming a rich air-fuel mixture $(\Phi=4)$. The fuel molecules are decomposed in the presence of oxygen creating free radicals $\mathrm{OH}^{*}$ that initiate the fuel self-ignition at a high temperature. The self-ignition of the air-fuel mixture results in an abrupt uncontrolled combustion of fuel releasing a great amount of heat in a short time. The oxygen used in this phase creates $\mathrm{CO}$ and the products of incomplete combustion. As a result of high temperature $(1600 \mathrm{~K})$ and the lack of a sufficient amount of oxygen $(\Phi=2-3)$ in the air-fuel mixture in this phase of the combustion process fuel pyrolysis takes place to saturated hydrocarbons and acetylene that are the precursors of polyacetylenes and polycyclic aromatic hydrocarbons locally forming small particles referred to as 'soot seeds' of the diameter of 1.5 to $2.0 \mathrm{~nm}[29,30]$.

The products of the kinetic combustion of a rich air-fuel mixture are transported outside where, on the boundaries of the combusted fuel spray, the available oxygen forms a jest cienką podwójną warstwą pomiędzy palącą się strugą paliwa a otaczającym ją powietrzem o wysokiej temperaturze. Przy kącie $10,0^{\circ} \mathrm{OWK}$ po wtrysku paliwa płonąca struga paliwa osiąga stan quasi-ustalony, w którym utworzony w czołowej części strugi wir zwiększa stężenie cząstek sadzy jak również powoduje ich aglomerację do cząstek o średnicy 30 do $50 \mathrm{~nm}$.

Rysunek 8 przedstawia zintegrowany model procesu spalania strugi paliwa począwszy od wtrysku paliwa do jego zakończenia z zaznaczeniem kinetyki zachodzących procesów chemicznych i rozkładu temperatury [20, 21].

Szczegółowy opis koncepcyjnego modelu potwierdzonego szczegółowymi badaniami z użyciem różnych technik przedstawiono w publikacjach [22-28].

Paliwo o temperaturze $350 \mathrm{~K}$ wtryśnięte do komory spalania, miesza się z gorącym powietrzem (950 K) i odparowuje tworząc bogatą mieszankę paliwo/powietrze $(\Phi=$ =4). Cząsteczki paliwa ulegają w obecności tlenu rozkładowi generując wolne rodniki OH', które w wysokiej temperaturze inicjują samozapłon paliwa. Samozapłon mieszaniny paliwopowietrze powoduje gwałtowne niekontrolowane spalanie paliwa wyzwalając w krótkim czasie dużą ilość ciepła . Zużyty w tej fazie spalania tlen tworzy $\mathrm{CO}$ i produkty niecałkowitego spalania. W wyniku wysokiej temperatury (1600 K) i braku należytej ilości tlenu $(\Phi=2-3)$ w mieszance paliwo-powietrze $\mathrm{w}$ tej fazie procesu spalania następuje piroliza paliwa do nienasyconych węglowodorów i acetylenu będących prekursorami poliacetylenów oraz wielopierścieniowych węglowodorów aromatycznych, które lokalnie tworzą małe cząstki zwane zarodkami sadzy o średnicy 1,5 do 2,0 nm [29, 30].

Produkty spalania kinetycznego bogatej mieszanki paliwo-powietrze transportowane są na zewnątrz, gdzie na

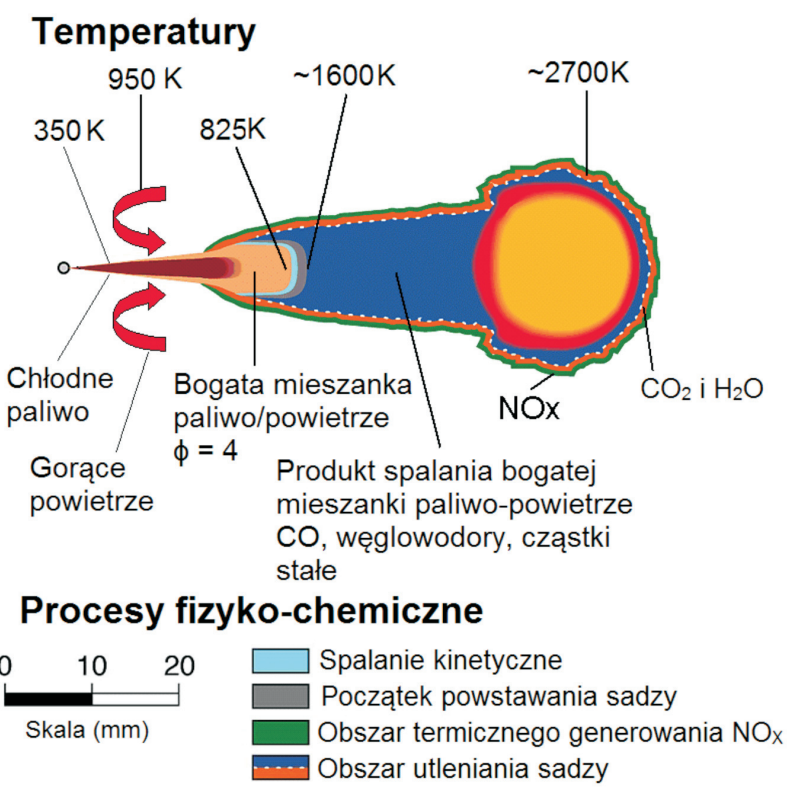

Fig. 8. The conceptual model of the process of combustion of a fuel spray in a direct injected diesel engine according to Dec and Flynn

Rys. 8. Koncepcyjny model procesu spalania strugi paliwa w silniku o zapłonie samoczynnym z bezpośrednim wtryskiem wedtug Dec'a i Flynna 

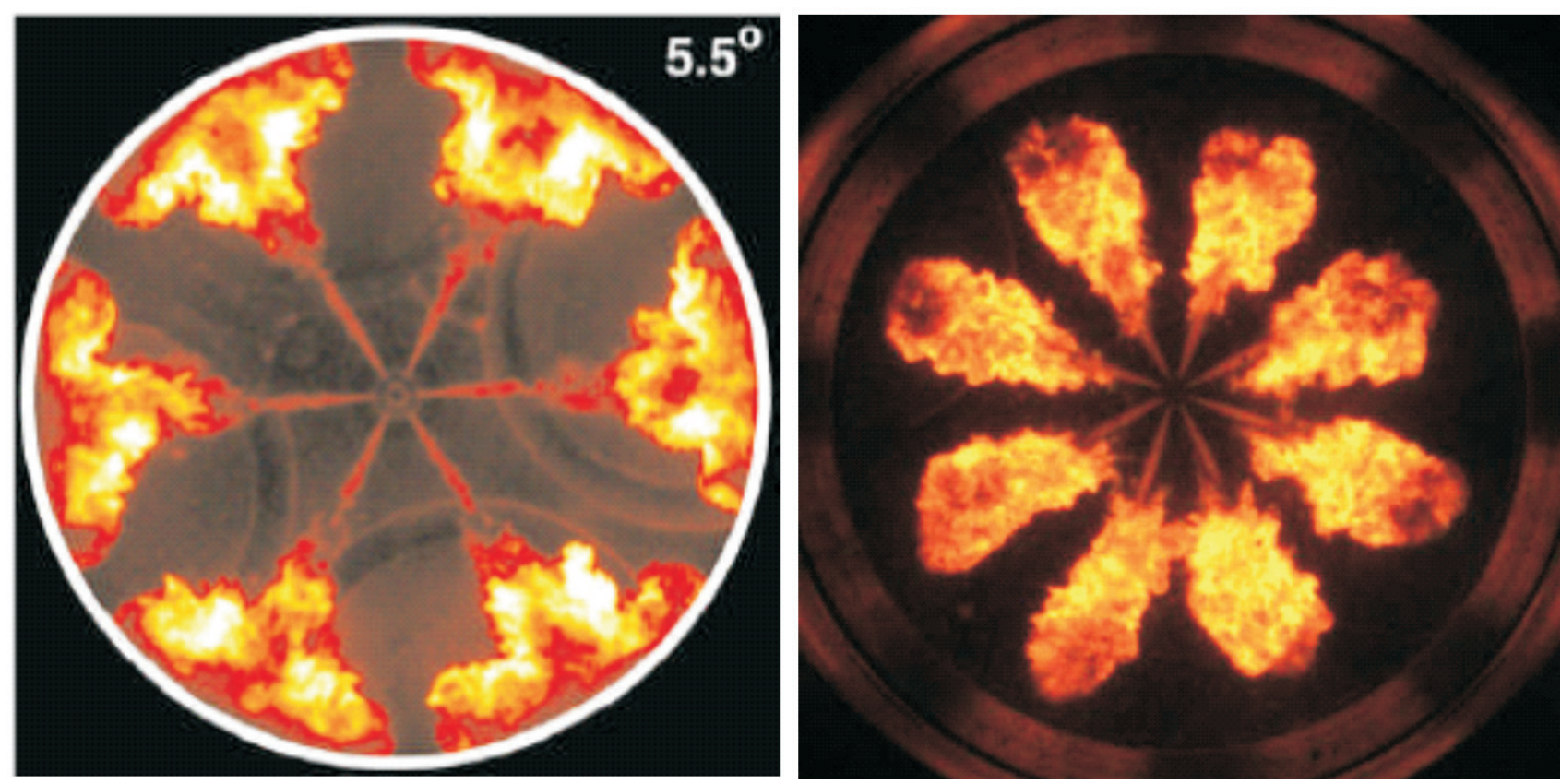

Fig. 9. The image of the flame development in a conventional direct injected diesel engine [36]

Rys. 9. Zdjęcie rozwoju płomienia w konwencjonalnym silniku o zapłonie samoczynnym z bezpośrednim wtryskiem [36]

diffusive flame reaching the temperature of $2700 \mathrm{~K}$ at the stoichiometry coefficient of approximately $\Phi=0.7-1$. The heat generated during the controlled oxidation causes a shortening of the liquid fuel spray and a shift of the flame towards the injector. The distance from the diffusive flame to the injector is called 'flame lift-off length' (FLoL) [31].

The FLoL value is responsible for supplying greater amount of oxygen to the liquid fuel spray in the air-fuel mixture under formation and influences the process of formation and oxidation of soot. The influence of the flame liftoff length on the amount of soot in direct injected diesel engines is a subject of many publications [32-35].

Figure 9 presents images of the flame development in a conventional direct injected diesel engine in the phase of kinetic combustion at the crankshaft angle of $5.5^{\circ}$ after the injection of fuel and on the right side a diffusive flame lift off length visible [36].

\section{Conclusions}

The development works conducted in the last two decades have led to a situation that the performance of diesel engines has become similar to that of spark ignition engines at still much lower fuel consumption.

One of the factors facilitating the development of diesel engines was a full exploration of the issues related to the realization of high-pressure combustion and propagation of intercooled turbocharging. A reduction in the fuel consumption and exhaust emissions was achieved, particularly in modern direct injected engines. That also includes the engine performance comparable to that of spark ignition engines.

The introduction of direct injection to the combustion chamber located in the piston allows the application of obrzeżach płonącej strugi dostępny tlen tworzy płomień dyfuzyjny osiągając temperaturę $2700 \mathrm{~K}$ przy współczynniku stechiometrii około $\Phi=0,7-1$. Ciepło generowane podczas kontrolowanego utleniania powoduje skrócenie strugi ciekłego paliwa i przesunięcie płomienia do wtryskiwacza. Odległość od dyfuzyjnego płomienia do wtryskiwacza nazywana jest "flame lift-off length" (FLoL) - długością oderwanego płomienia [31].

Wartość FLoL odpowiada za dostarczenie większej ilości tlenu do strugi ciekłego paliwa w tworzonej mieszance paliwowo-powietrznej oraz wpływa na proces tworzenia i utleniania sadzy. Wpływ długości oderwanego płomienia na ilość tworzonej sadzy w silnikach o zapłonie samoczynnym z bezpośrednim wtryskiem jest przedmiotem wielu publikacji [32-35].

Na rysunku 9 przedstawiono zdjęcia rozwoju płomienia w konwencjonalnym silniku o zapłonie samoczynnym z bezpośrednim wtryskiem $\mathrm{w}$ fazie spalania kinetycznego przy kącie obrotu wału korbowego 5,5 ${ }^{\circ} \mathrm{OWK}$ po wtrysku paliwa oraz po prawej stronie płomień dyfuzyjny z widoczną długością oderwanego płomienia [36].

\section{Podsumowanie}

Prowadzone w ostatnich dwóch dekadach prace rozwojowe spowodowały, że parametry techniczne silników o zapłonie samoczynnym (ZS) zbliżyły się pod względem osiągów do silników o zapłonie iskrowym (ZI), przy wciąż znacznie mniejszym zużyciu paliwa.

Jednym z czynników sprzyjających rozwojowi silników o ZS było opanowanie problemów związanych z realizacją wysokociśnieniowego wtrysku, a także upowszechnienie turbodoładowania $\mathrm{z}$ jednoczesnym chłodzeniem powietrza doładowującego. Uzyskano dzięki temu zmniejszenie zużycia paliwa i ograniczenie emisji związków toksycznych, 
multi-hole injectors (common rail or unit injectors) thanks to which the fuel is better distributed in the combustion chamber.

The course of the combustion was modified by an introduction of piezoelectric injectors changing the diameter of the injection nozzles (from $0.123 \mathrm{~mm}$ to $0.117 \mathrm{~mm}$ ) and a reduction of their length to $0.85 \mathrm{~mm}$ at an increase of the injection pressure in the whole range of engine operation. In this way a better fuel atomization was obtained and the fuel spray penetration was increased while the possibility of injector coking was reduced.

To sum up, the optimum course of the combustion in a diesel engine depends on many factors such as:

- the design of the intake system and the combustion chamber;

- the design of the injection system and the type of injector;

- the characteristics of turbocharging, exhaust gas recirculation, the characteristics of the injection and atomization including injection pressure, duration of the injection, velocity of the injection, fuel spray penetration, vertical angle of the fuel spray, distribution of the Sauter droplet diameter and cavitation;

- the physical and chemical properties of the fuel i.e. viscosity, density, fractional composition, cetane number, lubricity and thermo-oxidation stability.

The paper was developed on the basis of the results of a statutory work at the Chair of Fuel Technology, task number 11.11.210.213. zwłaszcza w nowoczesnych jednostkach napędowych z wtryskiem bezpośrednim oraz dynamikę porównywalną $\mathrm{z}$ silnikami o zapłonie iskrowym.

Wprowadzenie bezpośredniego, centralnego wtrysku do komory spalania ukształtowanej w denku tłoka, pozwala na zastosowanie wtryskiwaczy wielootworowych (typu common rail lub pompowtryskiwaczy) dzięki którym lepiej rozprowadzane jest paliwo we wnętrzu komory spalania.

Przebieg spalania zmodyfikowano przez wprowadzenie piezoelektrycznych wtryskiwaczy zmieniając średnicę otworków rozpylaczy (z średnicy $0,123 \mathrm{~mm}$ na $0,117 \mathrm{~mm}$ ) i zmniejszenie ich długości do $0,85 \mathrm{~mm}$ przy jednoczesnym zwiększeniu ciśnienia wtrysku paliwa w całym zakresie pracy silnika. $\mathrm{W}$ ten sposób uzyskano lepsze rozpylenie paliwa oraz zwiększono zasięg strugi i zmniejszono możliwość koksowania paliwa na powierzchni rozpylacza.

Reasumując optymalny przebieg procesu spalania w silniku o ZS zależy od wielu czynników, jak:

- konstrukcji układu dolotowego i komory spalania;

- rozwiązania konstrukcyjnego układu wtryskowego i rodzaju wtryskiwacza;

- recyrkulacji spalin i charakterystyki doładowania;

- charakterystyki wtrysku i rozpylania, w tym ciśnienia wtrysku, czasu wtrysku; szybkości wtrysku, zasięgu strugi paliwa, kąta wierzchołkowego strugi, rozkładu średniej średnicy kropel Sautera, kawitacji;

- właściwościowości fizykochemicznych paliwa czyli lepkości, gęstości, składu frakcyjnego, liczby cetanowej, smarności, stabilności termooksydacyjnej.

Artykut zostat opracowany $w$ oparciu o wyniki badań pracy statutowej $w$ Katedrze Technologii Paliw, zadanie nr 11.11.210.213.

\section{Nomenclature/Skróty i oznaczenia}

\section{$\mathrm{NO}_{\mathrm{x}} \quad$ Nitrogen oxide/tlenki azotu}

${ }^{\circ} \mathrm{OWK}$ crankshaft angle/kat obrotu watu korbowego silnika

PM Particulate Matter/czastki state

WWA polycyclic aromatic hydrocarbons/wielopierścieniowe weglowodory aromatyczne
FLoL flame lift-off length/dlugość oderwanego ptomienia

$\mathrm{CO}_{2} \quad$ carbon dioxide/dwutlenek wegla

$\mathrm{CO} \quad$ carbon monoxide/tlenek węgla

ZS compression ignition engine/silnik o zaptonie samoczynnym

ZI spark ignition engine/silnik o zapłonie iskrowym

\section{Bibliography/Literatura}

[1] Stanik W., Jakóbiec J.: Proekologiczny rozwój technologii silników o zapłonie samoczynnym. Autobusy-Technika-Eksploatacja-Systemy transportowe, $\mathrm{Nr} 7-8$, str. 191-196.

[2] Rychter T., Teodorczyk A.: Teoria silników tłokowych. Wydawnictwo Komunikacji i Łączności, Warszawa 2006.

[3] Kitchen T.: Welcome to a technical overview of common rail diesel fuel systems.

[4] Jankowski A., Sęczyk J., Zbierski K.: Badania strugi paliwa rozpylanej przez układ wtryskowy common rail. Journal of KONES Internal Combustion Engines, Vol. 7, No 1-2, 228236, 2000.
[5] Vekoeven D., Vanhemelryck J.L., Bavitanol T.: Macroscopic and ignition characteristics of high-pressure sprays of singlecomponent fuels. SAE Paper 981069, 1998.

[6] Lai M.C., Wang T.C., Xie X.: Microscopic characterization of diesel sprays at VCO nozzle exit. SAE Paper 982542, 1998.

[7] Merker G.P., Schwarz C., Stiesch G., Otto F.: Simulating combustion, simulation of combustion and pollutant formation for engine-development. Springer-Verlag Berlin Heidelberg 2006.

[8] Idzior M., Lijewski P.: Możliwości określenia jakości rozpylenia paliwa przez wtryskiwacze silników ZS metodą badania 
parametrów strugi rozpylonego paliwa. Journal of KONES Internal Combustion Engines No 3-4, pp. 104-112, 2002.

[9] Idzior M., Karpiuk W., Borowczyk T.: Analiza wpływu temperatury biopaliw na makro- i mikrostrukturę rozpylanych strug. Postępy Nauki i Techniki nr 15, 54-64, 2012.

[10] Ambrozik A., Kruczyński S., Jakóbiec J., Orliński S.: Wpływ zasilania silnika spalinowego o zapłonie samoczynnym paliwem mineralnym i roślinnym na proces wtrysku oraz rozpad strugi paliwa. Journal of KONES Powertrain and transport, Vol. 13, No. 3, pp. 21-28, 2006.

[11] Pszczółkowski J.: Tworzenie i spalanie mieszaniny paliwa i powietrza podczas rozruchu silnika o zapłonie samoczynnym. Journal of KONES Internal Combustion Engines, No 1-2, pp. 225-232, 2002.

[12] Lotko W., Górski K.: Zasilanie silnika wysokoprężnego mieszaninami ON i EETB. WNT, Warszawa 2011.

[13] Jankowski A., Sandel A., Siemińska-Jankowska B.: Badania widma rozpylenia paliwa w systemie common rail do silników z zapłonem samoczynnym. Journal of KONES Internal Combustion Engines, No. 1-2, pp. 311-322, 2002.

[14] Stone R.: Introduction to internal combustion engines. SAE International, Warrendale, 1999.

[15] Heywood J.B.: Internal combustion engine fundamentals. McGrill-Hill, New York, 1988.

[16] Hiroyasu H., Arai M.: Structures of fuel sprays in diesel engines. SAE Paper 900475, 1990.

[17] Lakshminarayanan P.A., Aghaw Y.V.: Modeling diesel combustion. Springer Dordrevht, Heidelberg, London, New York, 2010.

[18] Baumgarten C.: Mixture formation in internal combustion engines. Springer, Berlin, Heidelberg 2006.

[19] Kuszewski H., Lejda K.: Wybrane metody ograniczenia toksyczności spalin silnika ZS w aspekcie limitów emisyjnych. Journal of KONES Powertrain and Transport Vol. 13, No. 1, pp. 279-287.

[20] Flynn P.F., Dec J.E., Westbrook Ch.K.: Diesel combustion: an integrated view combining laser diagnostics, chemical kinetics, and empirical validation. SAE Paper 1999-01-0509, 1999.

[21] Dec J.E.: Soot distribution a DI diesel engine using 2-D imaging of laser induced incandescence, elastic scattering and flame luminosity. SAE Paper 920115, 1992.

Stanik Winicjusz, MSc., Oil and Gas Institute, Kraków.

Mgr Winicjusz Stanik - Instytut Nafty i Gazu, Kraków.

e-mail: stanik@inig.pl

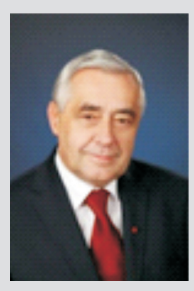

Jakóbiec Janusz, DSc., DEng. - Professor, Faculty of Energy and Fuels, AGH University of Science and Technology at Kraków.

Prof. nadzw. dr hab. inż. Janusz Jakóbiec - AGHAkademia Górniczo-Hutnicza w Krakowie, Wydziat Energetyki i Paliw.

e-mail:jjakobie@agh.edu.pl

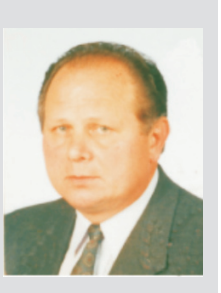

[22] Kamimoto T., Bae M.H.: High combustion temperature for the reduction of particulate in diesel engine. SAE Paper 880423, 1988.

[23] Dec J.E.: Advanced compression-ignition engines - understanding the in-cylinder process. Proceedings of the Combustion Institute, 32, 2727-2742, 2009.

[24] Kitamura T., Ito T.: Mechanism of smokeless diesel combustion with oxygenated fuels based on the dependence of the equivalence ratio and temperature on soot particle formation. International Journal of Engine Research 3(4), 223-248, 2002.

[25] Espey C., Dec J.E.: Diesel engine combustion studies in a newly designed optical - access engine using high-speed visualization and 2-D laser imaging. SAE Paper 930971, 1993.

[26] J.E. Dec, R.E. Canaan: PLIF imaging of NO formation in a DI diesel engine. SAE Paper 980147.

[27] Dec J.E., Espey C.: Chemiluminescence imaging of autoignition in a DI diesel engine, SAE Paper 982685, 1998.

[28] Dec J.E., Kelly-Zion P.L.: The effects of injection timing and diluent addition on late-combustion soot burnout in a DI diesel engine based on simultaneous 2-D imaging of $\mathrm{OH}$ and soot. SAE Paper 2000-01-0238, 2000.

[29] Tree D.R., Svensson K.I.: Soot processes in compression ignition engines. Progress in Energy and Combustion Science, Vol. 33, pp. 272-309, 2007.

[30] Kennedy I.M.: Models of soot formation and oxidation, Progress in Energy and Combustion Science, Vol. 23, pp. 95-132, 1997.

[31] Siebers D.L., Higgins B.: Flame lift-off on direct injection diesel sprays under quiescent conditions. SAE Paper 200101-0530, 2001.

[32] Czerwiński J., Zimmerli Y., Neubert T., A. Heitzer, Kaspar M.: Injection, combustion and (nano) particle emissions of a modern HD-diesel engine with GTL, RME and ROR. SAE Paper 2007-01-2015, 2007.

[33] Person H., Andersson O., Engel R.: Fuel effects on flame liftoff under diesel conditions. Combustion and Flame, Vol. 158, pp. 91-97, 2011.

[34] Donkerbrock A.J., Boot M.D., Luijten C.C.M., Dam N.J., Meulen J.J.: Flame lift-off length and soot production of oxygenated fuels in relation with ignition delay in DI heavy-duty diesel engine. Combustion and Flame, Vol. 158, pp. 525-538, 2011.

[35] Wang X., Huang Z., Kuti O.A., Zhang W., Nishida K.: An experimental investigation on spray, ignition and combustion characteristics of biodiesel. Proceedings of the Combustion Institute, Vol. 33, pp. 2071-2077, 2011.

[36] Merker G.M., Schwarz Ch., Teichmen R.: Combustion engines development: mixture formation, combustion, emissions and simulation. Springer 2012.

Wądrzyk Mariusz, MSc., Faculty of Energy and Fuels, AGH - University of Science and Technology at Kraków.

Mgr inż. Mariusz Wądrzyk,-AGH-Akademia Górniczo-Hutnicza w Krakowie, Wydzial Energetyki i Paliw.

e-mail:wadrzyk@agh.edu.pl

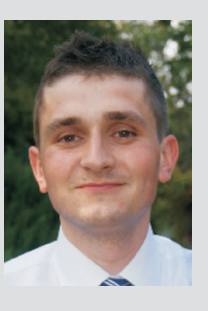

